\title{
Electoral Geography and Community: Whither Coalition Governments in Lesotho?
}

\author{
Vusi Mashinini ${ }^{1}$ \\ ${ }^{1}$ Professor, Department of Geography and Environmental Science, P.O. Roma 180, Lesotho
}

\begin{tabular}{|c|c|}
\hline \multirow{2}{*}{$\frac{\text { Article Info }}{\text { Article historv: }}$} & \multirow{2}{*}{$\begin{array}{l}\text { Abstract } \\
\text { Purpose: The aim of this research study is to address the nature, prospects }\end{array}$} \\
\hline & \\
\hline & and challenges of coalition governments and their impacts on the \\
\hline & community in Lesotho \\
\hline & $\begin{array}{l}\text { Approach/Methodology/Design: This paper uses desk top methodology and } \\
\text { employs a strengths, weaknesses, opportunities and threats (SWOT) analysis }\end{array}$ \\
\hline Кey & technique to address the nature, prospects and challenges of coalition \\
\hline Elects & governments and their impacts on the community in Lesotho. Research \\
\hline & questions that guide this study are what prompt coalition governments in \\
\hline & Lesotho? How do coalition governments operate in Lesotho? What are the \\
\hline $\begin{array}{l}\text { Coalition Government; } \\
\text { Lesotho. }\end{array}$ & $\begin{array}{l}\text { prospects and challenges of coalition governments on the government, } \\
\text { governance, lives and livelihoods of the communities in Lesotho? What }\end{array}$ \\
\hline & $\begin{array}{l}\text { might be a sustainable democratic coalition government option in Lesotho } \\
\text { going forward? }\end{array}$ \\
\hline & $\begin{array}{l}\text { Findings: The hypothesis of the paper is that coalition governments } \\
\text { promote instability of government and poor governance for the Basotho. The }\end{array}$ \\
\hline & results show that prospects for coalition governments are inclusive \\
\hline & $\begin{array}{l}\text { democracy, while challenges are community exclusion, poor service } \\
\text { delivery, extravagant public expenditure and government instability. }\end{array}$ \\
\hline Corresponding Author: & $\begin{array}{l}\text { Practical Implications: The article provides a detailed analysis of the } \\
\text { impact of coalition governments on the community. }\end{array}$ \\
\hline Vusi Mashinini & $\begin{array}{l}\text { Originality/value: The major findings and conclusion of the paper is that } \\
\text { coalition governments have prompted cooperation among former rival }\end{array}$ \\
\hline Emai & parties to form one coalition government at different times; but they have \\
\hline vi.mashinini@nul.1s & $\begin{array}{l}\text { had a negative impact on the Basotho community as a whole and benefited } \\
\text { only a minority aligned to some of the major coalition parties under } \\
\text { different coalition regimes. }\end{array}$ \\
\hline
\end{tabular}

\section{Introduction}

Since 2012 Lesotho has been embattled in the struggle to institute sustainable political, social and economic stability for Basotho under different coalition governments without much success. The biggest challenge of government has been that due to failure by parties to gunner enough parliamentary seats that would enable them to accede to power to run government as a single party with a majority rule as stipulated in the constitution, they have had to form post election coalitions to be able to accede to power to run government under coalition arrangements. While the electoral law allows parties to make these coalitions if necessary, they have been faced with insurmountable challenges in terms of their participatory democratic basis emanating from the Basotho community and the coalition 
parties cooperation themselves that has seen them fail to last for the five year normal constitutional government tenure and collapse within around two years instead.

This has resulted in Lesotho going for elections 3 times in a time frame of about five years which should have been the tenure of only one government since 2012 - 2017 with high political, social and economic consequences and impacts on Basotho. This paper interrogates the experiences of Lesotho under these coalition governments by assessing their prospects and challenges via the use of a SWOT technique. The major findings and conclusion of the paper is that coalition governments have prompted cooperation among former rival parties to form one coalition government at different times; but they have had a negative impact on the Basotho community as a whole and benefited only a minority aligned to some of the major coalition parties under different coalition regimes. In the process it has undermined the democratic basis of democracy since any group of parties can form a coalition government as long as they can come up with 61 seats needed for majority rule out of the 120 parliamentary seats. This paper recommends that electoral reforms that make it mandatory for grand coalition should be made in the constitution to enhance community-wide and driven participatory democracy in Lesotho.

\section{Coalition Governments and Communities in Africa: A Conceptual Overview}

Electoral Geography is defined as a sub - field or branch of Political Geography that deals with the elections within a specified geographic or spatial unit which may be at local, regional, national or international levels. Johnston et al. (1994, p.157) define Electoral Geography as "the study of the geographical aspects of the organisation, conduct and results of elections". Community is itself defined as "a social network of interacting individuals, usually concentrated into a defined territory" (Johnston et al., 1994, p.80).

Johnston et al. (1994, p.157-158) argue that Electoral Geography focuses on five areas; the first is spatial organisation of elections especially delineation and use of electoral districts or constituencies; the second is issues of spatial differences in voting patterns or cleavage effects; thirdly comes the issues of how locality has influences on voting choice and preferences which results in friends and neighbours effects or home turf electoral popularity and preferences for candidates and/ or parties. The fourth focus is on spatial aspects and patterns in election representation which deals with how votes are translated into parliamentary seats and their spatial patterns. The fifth area of focus is spatial differences in power and policy implementation, with a specific bias on pork barrel effects and vice versa.

Glassner and Fahrer (2004, p. 182-184) corroborate the five areas of focus of Electoral Geography as firstly the "geography of voting ... which explains the patterns of voting after an election" (Glassner \& Fahrer, 2004, p.182). The second area is the "geographic influences on voting ... which deals with voting on issues, voting for candidates, effects of election campaigns and the neighbourhood effect" (Glassner and Fahrer, 2004, p.182). The third area of focus is the geography of representation in which electoral systems/ models and units or 
districts or constituencies are discussed and analysed since they closely influence and are intertwined with the issue of community representation. The fourth area is the geography of political parties which deals with the party origins and performances / contextual and neighbourhood effects; while the fifth is the geography of election outputs which deals with interalia, organisation and policy performance of officials voted in to power positions in the elections. Government is formed by elected officials or candidates of parties that have won the elections in polling districts and become members of parliament that form government. Therefore the type of government that they choose to form under the constitution becomes one of the first behavioural patterns of voting outputs in terms of the performance of elected officials. Thus in this way then, types of government chosen by the incoming parties when they accede to power is a critical area of Electoral Geography because it is the government which is an institution they will activate to deliver tangible outputs to the community of voters and non voters alike or selectively to deliver goods and services for the nation. To this end Johnston et al. (1994, p.158) argue that:

"The outcome of an election gives power to individuals and groups within the STATE APPARATUS, who may use it to promote their own interests, including their own re-election through the selective allocation of PUBLIC GOODS”.

Therefore analysis of these types of governments and their prospective positive and negative impacts on the community or electorate befits analysis in Electoral Geography. In this way there is a symbiotic, but not necessarily symmetric relationship between Electoral Geography and community in which Electoral Geography drives community and community drives Electoral Geography.

In many African countries coalition governments have become common lately (Kadima, undated, 1). Coalition is defined as the association or alliance of two or more parties to contest elections before they are held and/ or to form government after the election outcome or results. Coalition governments themselves are a product of election results because they are formed after an election has produced a hung government in which there is no single one of the competing parties which has attained a parliamentary/ legislative majority vote where a country's electoral law and constitution requires it as a precondition to form and run a single party government on its own. Hence the necessity to seek the alliance of other parties with which to combine seats to form the minimum requisite $51 \%$ of all parliamentary seats to form government. Types of coalition government might be discussed on the basis of how they are formed. In some countries the law specifies that after in the case of a hung government as an election result the top two parties must come together to form a Grand Coalition (GC) government which would reflect the interests of the majority of the community as expressed through the ballots about who they need to govern them, and therefore as such become a true reflection of popular choice of and representation of the community in government under democracy. However, in other countries the party with the highest number of parliamentary seats is directed by law to be the one that should look for alliance partners with whom to form 
a coalition government among those of its choice with lower seats other than the party that is second to it per se, in which it would be the dominant player. Yet in other countries this issue is left open so that even the parties with lower a number of seats can come together to gang up against the one with most seats and form their own coalition government for as long as their combined seats would meet the minimum required for majority seats in parliament to form a government. In yet other countries the case of a hung government the law might allow the party with most seats to accommodate all other parties with seats in parliament to form a government of national unity (GNU) without any of them becoming the opposition.

Notwithstanding types, coalition governments have prospects and constraints unto themselves and more importantly to the community that is the electorate. In the case of prospects there are political, economic and social positive and negative impacts that they have on communities. Politically the assemblage of more than one party to form and run government promotes inclusive and participatory democracy since different party ideologies, manifestos and programmes of action are going to be combined together to produce the coalition government program and policies for implementation to deliver goods and services to the community. This is more likely to reach out to the bigger community of members from the different parties and thus the nation than might have been the case under single party majority government. Moreover, especially in Africa where nepotism, bribery, corruption and lack of transparency in public expenditure are rife, this harmonisation might reduce the cleavage effect and minimise pork barrel effects in government spending since the coalition partners might act as checks and balances of one another. Therefore more constituencies and communities might participate in and benefit from government decision making and spending (DPIR, 2015, p.1-2). Coalition governments might also be used as a ladder to promote reconciliation among rival parties and enhance peace, security and political stability of communities at local, regional and national levels in countries laden with political rivalry and conflicts. This was attempted as the case in Zimbabwe under the GC of the Mugabe and Changarai coalition of 2008, and the GNU of 2009. It was also the case in South Africa between the Mandela and De Klerk GU after democratisation; and in Kenya between Mwai Kibaki's Party of National Unity and Rila Odinga's Orange Democratic Movement in 2007 (Oloo, 2010, p.1).

Political disadvantages are that coalition governments may actually promote a gang up effect that operates on peer pressure mentality to make decisions and do policies that benefit the group alone at the expense of the community per se. This becomes aggravated by the fact that often the community is not considered for approval of coalitions. Rather, the coalition is treated as a political "business" transaction that is done by and to benefit the elected members of parliament for the parties that have seats together with some members of their national executive committees, all of whom constitute the party elites. This is done without prior consultation and approval of the ordinary rank and file of membership of the prospective coalition party members. Therefore, coalitions are mostly based on and promote the rape of participatory and popular democracy demonstrated in the election. Coalitions also promote what DPIR (2015, p.2) calls "exchange of favours" such as cabinet posts, principal 
secretaries, ambassadorships and others among the coalition parties without community consultations and sometimes outside the rule of law (Kadima, p. 15). For these reasons, interalia, coalition governments promote political and election apathy in the community, demonstrated by low turnover by the electorate at polling stations to vote in countries that practice coalitions recurrently in Africa.

In the case of economic impacts positive results might arise from inclusive income, employment and alternative livelihood strategies for the community as envisioned and encouraged by the coalition parties. However, the challenges are that expenditure is increased to maintain the coalition itself via economic favours that increase government expenditure on the selected few (DPIR, 2015, p.2). Moreover, since most coalitions do not last for the legal constitutional time frame of government and collapse within shorter time frames, they necessitate the holding of recurrent elections at a very high economic cost to the nation in terms of the opportunity cost of the resources to have been used to increase the delivery of more and/ or better quality goods and services to the community. In Africa where the resources are scarce, this presents a serious economic challenge for the support to economic development programmes meant for the betterment of the lives and livelihoods of the community (Loo, 2010, p.8). Moreover, the short life spans of coalition governments promote the "eat quickly, time up is near syndrome". This leads the elites of parties participating in the coalition governments and their selected supporters to engage in accelerated squander and corrupt use of public resources without public transparency and legitimacy for self accumulation and enrichment such as, interalia, hefty pay packets, work and end of work benefits, bloated cabinet and other senior positions in government and embassies, and privileged access to big tenders to accommodate the whims of all parties at the expense of the community and its development (DPIR, 2015, p.2). In fact, in some countries the collapse of coalition agreements is precipitated by disagreements on these corrupt economic gains among the coalition government party elites.

As far as social impacts are concerned, coalition governments can promote social inclusion, cohesion and integration among previous rival social factions on the basis of, interalia, ethnic, gender, regional, linguistic and tribal intolerance accentuated by different party membership. This might reduce the negative impacts of the cleavage and friends and neighbours effects with respect to different parties and their candidates who are members of parliament and are therefore in the coalition government. However the challenge remains as to what would be its benefit for the community. In an effort to promote community benefits, parliament members of coalition governments also use pork barrel politics and government spending as a mechanism to enforce social integration in their home communities. The problem becomes that the beneficiaries in the barrel projects remain chosen on partisan coalition basis to the exclusion of the other members of the community who are not their party supporters. Thus social marginalisation is promoted by coalition governments, especially in Africa where due to the politics of hunger, community members are forced to put their voting fingers where their mouths are or let life opportunities pass them by (Kadima, p. 17). 


\section{Lesotho's Electoral Model: A Descriptive Overview}

Lesotho uses a Mixed Member Proportional (MMP) electoral model since 2002. The choice of the MMP model came about after many violent internal political upheavals due to the refusal by parties which lost the election under the First Past The Post (FPTP) electoral model used from 1965 - 1998 to accept the election result and outcome ( Weisfelder, p. 53). The MMP electoral model in Lesotho is based on a mixture of the FPTP and the Proportional Representation (PR). Under the FPTP electoral model there are 80 electoral districts or constituencies nationwide in Lesotho in which constituency elections among competing candidates are held during the time of a national election. Invariably parties which compete for the election out of the 30 currently registered parties by the Independent Electoral Commission, field candidates under their banner; but there are, in some cases, independent candidates as well who stand on their own without any association to and with any party. Here the winner takes it all. These also constitute the first 80 seats in parliament. Then there are 40 additional separate seats which are competed for under PR in which each party submits a list of 40 party members all or part of whom would occupy the 40 or a proportion of them in accordance with each party's entitlement based on the overall election numbers of votes it has received nationwide. The overall parliamentary seats in Lesotho are 80 constituency seats plus 40 PR seats which adds up to 120 parliamentary seats in a total.

The share of a party in the $40 \mathrm{PR}$ seats is dependent on the number of votes it has from constituencies' votes as proportion of the overall parliamentary sets. This is done in the following manner:

- First the total votes for each party from constituencies are collected and counted.

- Secondly all these party votes are added up to find the total number of votes in that election.

- Thirdly, a party's share is determined by dividing these total overall votes by 120 seats to determine the numeric value of a seat.

- Fourthly the votes for each party are divided by that numeric value of a seat to determine how many seats it is entitled to in parliament. That number of seats is regarded as a provisional allocation only.

- Fifthly, the share of 40 PR seats that a party is entitled to is determined by subtracting its constituency seats from the provisional parliamentary seats. The residual or difference become the compensatory seats that it is entitled to from its PR list ranked in order of priority from which the IEC then nominates and reads out the names according to that order.

In order to be more inclusive parties without a single constituency seat are given first priority when the rounding up to the nearest whole number is done in cases where there are decimal point outcomes. This gives opportunity to small parties to have a seat in parliament where they can. The MMP electoral model also requires that a party must not just have a numeric 
lead, but this must form a majority of the 120 seats in order to form a single party government. Therefore the minimum number of parliamentary seats required by electoral law to form government in Lesotho is 61 seats. In the event that there is no party which attains the 61 sets alone and therefore there is a hung government, the law under the constitution further makes provision for parties to make a coalition by pulling together their parliamentary seats to make up the requisite 61 seats to be able to make a coalition government.

While the MMP electoral model in Lesotho has been heralded as the big success for promoting political stability because of its inclusive nature of the smaller and looser parties; and thus enhancing and deepening democracy it has also had disastrous effects on the communities. Firstly, the rationale for the extra 40 seats has no social/ community basis because it very indirectly emanates from a people's mandate. Rather it is a gentlemen's consolation reward by and meant to appease the political elites who the communities have rejected in the polls. This spits saliva in the face of the communities as the electorate. It is a negation of democracy as expressed through the free and fair voting by the communities themselves through their approved and rejected candidates and parties at the polls. Secondly, due to lack of intra-party democracy in Lesotho, the selection and ranking of nominees in the party list for inclusion into PR position where possible is done by party national executive committees instead of party supporters and structures at lower community levels. Instead they are just told of this decision from the top party structure. This is a negation of democracy, but promotion of party authoritarianism on its followers who are its community. The third issue is that of community accountability of the PR parliamentarians; to whom are they responsible? Whose community mandate do they represent and to whom do they report the results of their participation in the parliamentary decision making and policies to as the product of their representation?

The other impacts of the MMP model are economic in nature. An increase of 40 more seats which amount to half of the 80 FPTP derived seats elected directly by communities at constituencies is an unnecessary undemocratic expansion of parliament membership and its effects as a financial burden to a poor economy of Lesotho. The salaries and work benefits that accrue to these $40 \mathrm{PR}$ members of parliament are a direct robbery to the communities because they could have been used to finance enhancement of quantity and quality of service delivery to the communities. Therefore their appointment promotes community injustice. Therefore the minimum number of parliamentary seats required by electoral law regulated under the Constitution of Lesotho 1993 section 87(2) to form government in Lesotho is 61 seats (Letsie, 2015, p. 83).

\section{Coalition Governments and their impacts on Community in Lesotho: An Interrogation}

\section{1: Coalition Governments in Lesotho: A Temporal Overview}


Lesotho experienced her first coalition government in 2012 following a hung government after the national election in which the then newly formed Democratic Congress (DC) had a lead in the numeric parliamentary seats from the national election of 26th May, 2012. The results were DC with 48; All Basotho Convention (ABC) with 30; Lesotho Congress for Democracy (LCD) with 26; Popular Front for Democracy (PFD) with 3 seats; Basotho National Party (BNP) had 5; Marematlou Freedom Party (MFP) had 1; National Independence Party (NIP) had 2; Basotho Congress Party (BCP) was 1; Lesotho Peoples Party had 1; Basotho Democratic National Party (BDNP) had 1; Lesotho Workers Party had 1, and Basotho Batho Democratic Party had 1. Due to the fact that the constitution is open on coalition formation, it was the ABC, LCD and BNP that moved quickly to pull their parliamentary seats together to form a coalition government made up of exactly 61 seats required as the minimum by the majority rule clause. They called their government the "Letsema" translatable to work party. The DC was marginalised to become the opposition in parliament despite the fact that it had the single party popular lead in parliamentary seats. Two years down the line in 2014 the coalition collapsed due to lack of trust, poor coordination of leadership, misunderstandings on policies and vision among the coalition parties, particularly the ABC and LCD which precipitated a lot of foreign interventions by SADC and a series of community mishaps that soured the coalition rule in the face of the public (Mahlakeng, 2016; Letsie, 2015).

The snap election of 28 February, 2015 meant to produce a successor government resulted in a hung government too in which the parliamentary seats were as follows: DC had 47; ABC had 46: PFD had 2; LCD had 12; BNP had 7; NIP had 1; MFP was 1; BCP was 1; Reformed Congress of Lesotho (RCL) had 2. The DC was quick to solicit coalition partners this time around to oust the $\mathrm{ABC}$ which had second most parliamentary seats to get an outright majority vote of 61 seats required to form government alone. The DC; LCD; PFD; MFP; BCP; NIP; LPC formed a seven party coalition government with combined 65 sets in all. They called their coalition "Khokanyana phiri" or later "Let'soele le beta Poho" translatable to unity is strength. This coalition worked well in the beginning but also collapsed after about two years when internal conflicts in the lead party the DC caused a split in it that resulted in floor crossing of 13 of its parliament members with 13 seats which made it have below the 61 majority seats, and a motion of no confidence passed against it in parliament in February, 2017.

A snap election was again called for targeted for three months on $3^{\text {rd }}$ June, 2017 as spelled out in the constitution. The results of this snap election again resulted in a hung government without a single party with outright majority seats of 61 in parliament to form government. All in all the allocation of parliamentary seats by party was ABC had 49; DC had 30; LCD had 11; Alliance of Democrats (AD had 9; Movement for Economic Change (MEC) had 6; BNP had 5; PFD had 3; NIP had 1; MFP had 1; BCP had 1; Democratic Party of Lesotho (DPL) had 1. The ABC which had most, 49 seats formed a coalition government with the Alliance of Democrats, a new part formed by the breakaway faction from the DC that lead to the fall of the seven party coalition 3 months earlier with 9 seats; the BNP with 5 seats; and 
the Reformed Congress of Lesotho (RCL) which is also a new party of breakaway people from the LCD with 1 seat. This formed a total of 163 seats initially. Three constituency elections had been postponed because some candidates passed away just before the snap elections. Nonetheless this did not deter or hinder the finalisation of forming the coalition government because the majority seats of 61 had been attained already. In line with their number, these four parties named their government a $4 x 4$ coalition government. This coalition government collapsed on the $11^{\text {th }}$ May, 2020 when two of its coalition partners the Basotho National Party and the Reformed Congress of Lesotho withdrew from it in parliament and left the All Basotho Convention and Alliance of Democrats without a majority in parliament. This was prompted by the fact that an intra party conflict within the All Basotho Convention which had stated in February 2019 had left the party divided into two major factions one of which had gone into an alliance with the opposition Democratic Congress and the other smaller parties all of whom were proposing to declare a motion of no confidence in the Prime Minister and his remaining faction of the All Basotho Convention and its $4 \times 4$ coalition. Since at the end of April, 2020, the parliamentarians had passed a motion that change of government and Prime Minister could take place in parliament without the Prime Minister advising the King to call a general election, on $11^{\text {th }}$ May, 2020 change of government took place in parliament and a new Prime Minister Dr Moeketsi Majoro was sworn into office on $20^{\text {th }}$ May, 2020 to lead the new government between All Basotho Convention and Democratic Congress as the two major coalition partners, but with the support from eight other smaller parties. There is much anxiety about how this self appointed coalition government will perform because unlike in the other 3 former cases this one was formed in parliament without going to seek an electoral mandate from the people for the parties to be in parliament before making this coalition. However, latest indications are that Basotho have lost confidence in the government and democracy in Lesotho (Sunday Express, 2020).

\section{Coalition Governments in Lesotho: A SWOT Analysis}

SWOT is an acronym for opportunities, threats, weaknesses, and strengths. Opportunities are all positive aspects of the environment both international and national within which a policy, planned action or public institution operates and have a bearing directly or indirectly on its outputs or performance. Threats are all negative environment factors; Strengths are all internal strong and positive impacts of an institution, policy or program; while Weaknesses are its negative internal impacts or performances.

\section{i. Opportunities}

There are many opportunities that have been present in the external environment of Lesotho's coalition governments which have made them to have positive impacts on the community. In the case of political opportunities the presence and magnanimity of the United Nations through its UNDP office in Lesotho, The African Union; and in particular the Southern African Development Community (SADC), South Africa and Botswana all stand out 
prominently (Vhumbunu, 2015; Weisfelder, p. 53). The first participation of SADC to support political stability in Lesotho dates back to 1994 when South Africa, Zimbabwe and Botswana were appointed by SADC as guarantor states for political stability in Lesotho following the refusal of the opposition to accept the landslide victory of the BCP in the 1993 national election; and the quo against the BCP government made by King Letsie III himself as Head of State. This palace quo prompted the intervention by Presidents Nelson Mandela, Robert Mugabe and Ketumile Masire respectively as mediators of the restoration of the BCP democratic government (Mothibe, 1999: 48-49; Matlosa \& Pule, undated: 54-55). The second major SADC intervention was through the SADC military intervention of 1998 (Mothibe, 1999; Likoti, 2006). This was followed by its SADC mediation facilitation of 2007 (Wiesfelder, 2007; Vhumbunu, 2015). Since 2012, SADC has played the continuous role of peace mediator until today. In the 2012- 2014 coalition it was Angola, Botswana and then South Africa that were mediators in their role as the chairpersons of the SADC political organ respectively. It was then that the then Deputy President, and now current President of South Africa, His Excellency Cyril Ramaphosa became the SADC mediator in Lesotho; and due to continuous and irreconcilable differences in running the government and even at table negotiations between the leaders of the major parties ABC and LCD in the coalition government called for a truce through the Maseru Facilitation Agreement that saw the end of prorogation of parliament and its reopening in September, 2014 and the call for a popular vote under the first snap election due for $28^{\text {th }}$ February, 2015.; And the Maseru Security Accord which was meant to enable a truce among the army and police by having their leaders take leave of absence outside the country (Letsie, 2015, p.84). Since the 2012; 2015 and current 2017 to today, Lesotho's coalition politics, governments and stability have been supported through and overseen by SADC throughout via his person until he was relieved lately of this duty after he became President of South Africa. Therefore so intensive has been SADC tutelage of the coalition governments in Lesotho that former Prime Minister Mosisili of DC complained that Lesotho seems to have surrendered its sovereignty to and was now ruled by SADC. However, this positive role is heralded for enabling community to participate in the re - expression of its democratic mandate on who should rule it in the snap elections.

Moreover, in the security arena, in 2014 SADC, through South Africa, supplied the then Prime Minister Tom Thabane with police and dogs as his guard in Lesotho to replace the military after he ran away to South Africa to seek protection as a result of what some regard as a failed quo attempt by the military in August, 2014 following his firing of the then substantive military boss and his replacement with a new boss supposedly close to his party affiliation (Vhumbunu, 2015). SADC also followed this through with sending an emissary of some top military personnel to hold discussions with the then boss of the military in Lesotho who had just been fired by the Prime Minister to step down immediately and allow the return of Prime Minister Tom Thabane to Lesotho. There was also a SADC Oversight Committee established to stay in Lesotho as an eye keeper of peace and stability on a daily basis (Vhumbunu, 2015). Moreover, since December, 2017 to the present there is also a military advantage in that SADC has supplied Lesotho with a standby security force of soldiers to the total of 207 called SADC Preventive Mission in Lesotho (SUPMIL) which has been 
positioned in Maseru and in the communities to oversee peace and security following the assassination of Lt. Gen. K. Mots'omots'o in September, 2017 by two senior army officers. The SUPMIL is also expected to suppress internal renegades within the army; do some training on military-civil relations for the Lesotho Defence Force, discipline by security forces under the Lesotho Defence Force, Police Force and Prisons Forces as well (Lesotho Times, 2018a; Qaitsane, 2018a).

Other opportunities are in the economic field. External donor agencies like the European Union (EU) and foreign countries with embassies in Lesotho such as the United States of America and People's Republic of China, interalia, have played a supportive contribution in the financial support they have extended towards successive snap election finance and to successive coalition government regimes worth millions of Rands to top up meagre government finance for this recurring exercise and rapid turnover of governments. Moreover these various countries and organisations have provided human and logistics resources support with election observers to monitor that the elections are free and fair and thus a democratic reflection of community participation and choices.

Social opportunities also help coalition governments in that some members in the leadership of major opposition parties often run away especially to South Africa's Free State Province which is not only nearest to sneak into geographically, but is populated by Basotho who are blood brothers and sisters to the Basotho of Lesotho. In particular Ficksburg and Ladybrand towns have become asylum homes of political refugees from Lesotho and have welcomed them with open hearts. This has cemented the bonds of brotherhood, sisterhood and neighbourliness between South Africa and Lesotho alike, as Lesotho also hosted South African political refugees during the apartheid era.

\section{ii. Threats}

Threats are also present in the external environment that poses challenges with which coalition governments are faced. Politically, firstly, the continuous involvement of SADC and its support also promotes a challenge to Lesotho's sovereignty. This was felt more during the controversy on whether the SADC report by the Phumaphi Commission which made recommendations of the current SADC reforms for Lesotho were binding or not and the then Prime minister Dr Pakalitha Mosisili was adamant that they were not binding because Lesotho is a sovereign state that could not be dictated to from outside; prompting a threat of economic boycotts from the SADC Troika (Mohloboli, 2016). Therefore as it were, the SADC reforms since then and currently driven by coalition governments in Lesotho are imposed on community rather than community driven. Secondly, the SADC also takes some of the decisions that are binding on communities without consultation with the communities at large except through representatives in the civil society groups, party leaders and community leaders. Representative participation and democracy is partial participation and democracy; and as such, ipso facto a partial denial of the communities of their full human rights. Thus Letsie (2015: 93) argues that "while all these developments (of arrangements for 
snap elections by SADC) unfolded, there was not a single effort to officially engage the opinion of the public". Thirdly, the issue of Tom Thabane as Prime Minister under the daily guard of a foreign security with its full armoury caused a threat to security protocol in Lesotho and was seen by some 72 parliamentarians in their joint statement on $15^{\text {th }}$ September, 2014 as its breach and an invasion of sovereignty by SADC (Weisfelder, undated: 65 \& 73). Other community members feared there was an external invasion similar to that of operation BOLEAS in 1998 when SADC forces from South Africa and Botswana invaded Lesotho on the behest of the then Prime Minister Pakalitha Mosisili who claimed there was a quo attempt by the opposition (Pherudi, 2003, p. 124). Moreover, an economic threat on the cost of payment to the security guard and its resources to be paid by Lesotho posed concern in terms of the opportunity cost to community investment.

Fourthly, the presence of the SADC standby force is viewed as a threat to peace and calm by some members of the communities who see its presence in their midst as efforts to intimidate them to be docile to repulsive acts by the present 2017 coalition government (Lesotho Times, $2018 b)$. Fifthly, there is continuous involvement of security forces especially the military and police in party political affairs which acts as a threat to stability of coalition governments, and the communities themselves rather than an asset for their security support (Qaitsane, 2018a:1\&2). The military is alleged to be pro-LCD and DC parties aligned while the police force is said to be pro-ABC and BNP parties aligned (Letsie, 2015, p. 83)

Threats in the area of economic support by outside agencies and governments relate firstly to the economic bail out of the coalition governments which seemingly makes them to be blind to the financial costs of their deliberate actions to terminate the sustainability of the coalition governments either through floor crossings and/ or lack of tolerance of differences, interalia. Moreover, there is waste of meagre domestic financial resources that government uses as its own contribution to finance snap elections at a high opportunity cost to community investments. Estimates are that it costs around R300 million to mount each election in Lesotho.

Secondly, another economic threat is that some of the major donor countries like the United States of America and donor agencies like the European Union have used their donor support as an instrument for political leverage on Lesotho (Weisfelder, nd: 57). Thus they promoted leniency to some unparliamentarily measures, and, have threatened to, at different times and different regimes, promised or threatened to cut on economic support to them unless they tore the line of their political preference in restoring political stability in the country. This became more pronounced during the post 2015 snap elections that gave birth to the second coalition or "Khokanyana Phiri" government, when both the USA and EU demanded that the Mosisili - led coalition government must remove the then military boss Lt. Gen. T.K. Kamoli as a way forward for political stability in Lesotho, or else they would withdraw their funding. This led to hot exchange of palliatives between the then Prime Minister and the representatives of these institutions and countries at that time (Lesotho Times, 2016); but Lesotho had to comply due to its poverty to save the communities from starvation. For instance, the USA or 
its then ambassador threatened to close down AGOA and Millennium Challenge Corporation (MCC) support to Lesotho with the implications that the nearly 40, 000 employees in the AGOA - led garment industries would be rendered jobless and income less, which prospect promoted contestations against that coalition government from both factory workers, some members of the community and some civil society organisations (Weisfelder, undated: 70). Moreover, the now ousted ex President Jacob Zuma also came out of a Troika Summit in Botswana in 2016 fuming with anger and asserting that South Africa and SADC would immediately cut economic trade ties with Lesotho if then Prime Minister Pakalitha Mosisili was adamant on refusing to take and implement the Phumaphi Report recommendations (Mohloboli, 2016). Again Lesotho had to oblige because the entire lives and livelihoods of Basotho are dependent on economic ties and flows with South Africa, failing which only disaster would have resulted for the communities.

Concerning threats in the area of social ties, there are also intolerable behavioural patterns that some self exiled Basotho and party leaders engage in which discomfort their host in South Africa. One such behaviour is the use of the South African territory as a springboard from which to launch a string of verbal attacks on and/ or threats to the ruling coalition government back in Lesotho. At other times they associate with the enemy camp/ parties in South Africa itself and pose a threat to its own stability. For instance, more recently LCD exiled leader made utterances from his birthday party held in Ladybrand that did not sit well with the current $4 x 4$ coalition government (Sejanamane, 2018). The ABC leadership in Ficksburg between 2015- 2016 was also becoming close with and starting to hold rallies with Julius Malema's Economic Freedom Front (EFF) there much to the dislike of the ANC government which had to call them to order as refugees. Moreover, progress on negotiations of free movement between Lesotho and South Africa continue to be hampered or stalled by different government temperatures as coalition governments' change in Lesotho. For instance the Lesotho Special Permit (LSP) negotiated by the 2015-2017 DC coalition government suddenly came to a halt when the ABC coalition took over in 2017 resulting in social scuffles and long queues in the facilitation of movement across the borders between South Africa and Lesotho which culminated in a scandal in which, contrary to protocol, even the King of Lesotho was humiliated in the subjection to the border search of his entourage and having himself to wait for a long time at the Maseru border - an issue which soured the foreign relations and compelled South Africa's foreign minister Hon. Lindiwe Sisulu to go to Lesotho to thaw the icy foreign relations during the first week of April, 2018 (African News Agency, 2018; Qaitsane, 2018a: 4).

\section{iii. Strengths}

Coalition governments in Lesotho have expressed much strength through impacts on community. In the case of political strengths they, firstly, promote deepening democracy due to their formation of pooling together seats from different parties in the pursuit to fulfil the majority vote rule of 61 seats in parliament. This also enables multiparty participation and democracy in parliament and government. The 2012-2014 coalition had 3 parties; 2015-2017 
coalition had seven parties; while the current 2017 + coalition has 4 parties forming government. In principle this offers opportunities for ideological and programme consolidation and integration that has positive results for community. For instance, while historically throughout their single party rule from 1993 - 2012 the Congress parties of BCP and LCD had been completely against any form of integration or shared citizenship with South Africa, under the coalition they had with PFD they warmed up to and entertained the idea of a possible dual citizenship arrangement once the constitutional bottleneck to this was reformed, all because of the PFD which has this as the focus of its party programme. Moreover, the leader of the PFD who was the Minister of Home Affairs then also negotiated for smoother free flow of movement between the two countries with positive impacts like the Special Permit for Basotho. This has become a problem in the current $\mathrm{ABC}$ coalition government time. Moreover, in the current coalition the ABC ideology has a focus on eradication of hunger and corruption; $\mathrm{AD}$ has a focus on national integration; RCL focuses on livelihoods; while BNP emphasizes prosperity. Integration of these has led to more focus on farming support, efforts at reconciliation of rival parties and their followers, peace and stability efforts and projects on better community livelihoods within the communities by the government ( $3^{\text {rd }}$ Coalition Government, 2017).

The second strength is that of promoting reconciliation among rival parties and followers. The coalition governments have made the congress parties to work with national parties in the same government unlike before when they were bitter rivals. In the 2012-2015 coalition the LCD was with its rival the ABC and BNP; in the 2015 - 2017 coalition the DC, LCD, BCP and LPC which are splinter parties from BCP and then LCD all put their differences aside, reconciled and worked together with NIP and PFD which are splinter parties from $\mathrm{BNP}$, and the MFP which is an old stand alone rival party to all of them. In the current 2017 coalition the $\mathrm{ABC}$ and $\mathrm{BNP}$ which advocated for the legal perusal and punishment against the $\mathrm{AD}$ leader for alleged cases of governance malpractices, have reconciled and work together as government in which the AD leader is the Deputy Prime Minister. All these reconciliations have promoted nation building and nationalism in the communities rather than former party factionalism and conflicts (Kapa \& Shale, p.110-111).

The other strength is that they have promoted inclusion of even the smaller parties in parliament to go into government if they agree to have alliance with the bigger parties which might approach them (Weisfelder, undated: 53-58/ Kapa \& Shale, p.105). In this way a more community inclusive participation in government is promoted.

Economic strengths have been that a coalition government would drive the parliament to be more stringent and watchful in its financial oversight role, and thus encourage a wider and intensive community investment and livelihoods promotion program as embodied in its coalition agreement (Kapa \& Shale, undated: 106).

\section{iv. Weaknesses}


Coalition governments have also had weaknesses which have undermined their performance and had negative impacts on community. In the case of political weaknesses coalition has failed to promote democracy in that the constitution allows any one of the parties with parliamentary seats to come together with others to form a coalition for as long as this would gain them majority seats of 61 in parliament. This has resulted in major parties which are $\mathrm{ABC}$ and DC separately seeking coalition alliances and the one which gets them first declaring to the Head of State that it is ready to form government with its allies instead of forcing them to come together under a grand coalition which would be a more realistic reflection of the majority of voters. Moreover, once the parties have parliament seats on the basis of votes by the community then the issue of who each partners with as an ally in coalition is no longer determined by the party followers who are its community, but by the party elites in the national executive committee and imposed later on the party followers from the top. Therefore, lack of intra-party democracy on the choice of coalition alliance partners violates democracy of coalition government formation via exclusion of community participation in it. The choice of who goes to cabinet and upper House/ Senate is equally in the arena of the party executive which then recommends their selected nominees to the Prime Minister (PM) in the coalition to appoint.

Yet another more of the weaknesses is that the constitution is not clear on who should be Prime Minister in the coalition except to say the one who has a bigger support of the members of parliament (Kapa \& Shale, undated: 105-106). A gentlemen's practice rather than law has been that the leader of the party with more seats in the coalition is given a chance by its alliance partners to be so and the Deputy Prime Minister becomes one with second high number of seats while the third in that row becomes the one who acts in the absence of the PM and DPM. This protocol has caused conflict in that sometimes it is violated by the PM who might prefer to work more closely with the third leader in the coalition alliance protocol rather his DPM. This became the case in the ABC, LCD and BNP coalition government of 2012-2015 and created an alliance rift and instability of that government until it broke down irreparably, warranting SADC intervention for table discussions which failed and resulted in an eventual call for a snap election by the SADC facilitator of peace and stability, Cyril Ramaphosa in October, 2014. In the meantime the community suffered from the security instability culminating in an attempted quo of August, 2014; loss of services as the soldiers caused a stall to some public services like electricity, radio and TV services; uncertainty and fear for the safety of their lives and properties as the wrath of the storm between the then PM - Tom Thabane and his then DPM - Mothejoa Metsing unleashed itself and affected them further, for instance, in the prorogation of parliament by the PM to avoid a motion of no confidence in parliament by the opposition (International Alliance Group, 2015; Weisfelder, nd: 64-65). This was after LCD leader formed a new alliance with the opposition DC party and announced it in public. "Re ferehane, "me re lumellane" literally translatable into "we proposed alliance partnership with each other, and we are in agreement", was the expression used by the DC leader in a public interview with newspapers on this matter. Again when alliances collapse party followers are never consulted for their opinion, rather it becomes the party elite in the party's national 
executive committee who make the decision and recall of the party out of the coalition alliance. In general, under coalition governments, democracy is nullified in that party supporters are carried around like a bundle of wood with no feelings, views and opinions from $\mathrm{A}$ to $\mathrm{Z}$ to fulfil the desires and destinations of the party elites for self aggrandisement (Weisfelder, undated: 67).

Political ideologies are never fused and compromised; instead they are sources of differences and create intolerance once allies are in coalition government. Part of the deep conflict between the ABC leader -Thabane - and the LCD leader - Metsing - arose when the former started to blame and institute investigation cases into what he alleged to be corruption cases against the latter. Moreover there seems to have been difference of views between them as to whether and what role the military should have in the country's affairs (Weisfelder, undated: 62-65).

As exemplified in the $3^{\text {rd }}$ Coalition Government Agreement 2017, another weakness is that the sharing of ministries, permanent secretaries, senators and ambassadors to be owned by each coalition party leads to a lot of conflict about which and how many ministries go to which party (Kapa \& Shale, undated: 106). This delays the commencement of a new coalition government and its service delivery to the community. Some differences and rifts form here and never heal but grow bigger over time until they cause the fall of the alliance. The conflicts are mostly over which fat ministries, meaning those with high opportunities for lucrative tenders or raising money, go to which party. Rapid turnover of principal secretaries, as each party expels some and replaces them with its own, results in law suits and lack of continuity which hamper efficient service delivery for the community. So is the case with recall of ambassadors in foreign countries. Corruption arises in employment which is exclusively or mainly granted to party members in a ministry that their parties control at the expense of transparent competition by all members of the community who apply for it (Kapa \& Shale, undated: 110). Another problem is that the cabinet size is increasing in order to accommodate favours via the appointment of some ministers from members of each coalition party (Kabi, 2017). Therefore ministries are either being split to increase sharing among parties instead of amalgamated to streamline functions, service delivery and cost effectiveness. Moreover, in some cases 2 to 3 ministers, like in the case of Ministry of Education and Training, are appointed to run the same ministry with drastic cost implications at the expense of enhanced quality and quantity of service delivery to the community.

In yet other political weaknesses the cases of floor crossing are endemic since the advent of coalition governments in Lesotho. Parties practice poaching in parliament and this results in some members of parliament with constituency seats crossing the floor with people's votes from one party to join the other parties of their own personal choice, especially those in coalition government, or they do so to form their own new party with which to join a coalition alliance or the opposition. This floor crossing decision is done unilaterally by the MPs without the consent and consensus of the community that voted them in at constituencies. In 2014 ABC's Tom Thabane prorogued parliament to avoid this move. In 
2017 the DC coalition government collapsed after some intra party scuffles resulted in some 13 of its MPs crossing the floor in parliament to form the AD and make an alliance with the opposition to express a motion of no confidence in the government in parliament which ended the DC led coalition government. Currently, after the 2017 election, four MPs have crossed the floor from the main opposition party - the DC. Two of these have joined the AD which is in the $4 x 4$ coalition and the two of them have been rewarded with posts of Minister of Development Planning and $2^{\text {nd }}$ Deputy Minister of Ministry of Education and Training. While the other two crossed the floor from the DC to join the ABC in which one of them has been offered the position of Minister in return. This is tantamount to hijacked democracy which nullifies and robs the he community of the fruits of its voted for choices in the ballot in terms of its constituency representation in parliament.

As far as economic weaknesses are concerned, coalition governments are wasteful of meagre financial resources in Lesotho. Firstly, every two years hundreds of millions of Rands are spent on snap elections without having been budgeted for; which means a viament of finance from some budgeted programs has to be made by compromising them and their benefits to the community. Secondly three times in a row as each coalition prematurely ends, all the members of lower house, some 120 of them, and members of upper house/ Senate accord themselves the right not to repay their loans of R500, 000 each in a new government. This is worse because parliamentarians are already, contrary to the law that every Mosotho except the King pays income tax and sales tax to the Lesotho Revenue Authority, exempted from paying tax and interest on this loan. So for them every two years they get manna from heaven worth half a Million Rands from the taxpayer's money. This means from 2012 to 2017, most of them have each R1.5 million in this way. The question then is what kind of parliamentary oversight function is this? Therefore coalition governments have become a mechanism for defrauding the state and the public of its financial resources by parliamentarians in Lesotho. Therefore, under coalition governments, parliamentarians are exercising state capture at the expense of the public in Lesotho. Consequently, the government is frequently declared broke since the advent of coalition governments; For instance while the budget for 2018/19 became effective only as of $1^{\text {st }}$ April, 2018 hardly 3 months later by $21^{\text {st }}$ June, 2018 the Minister of Finance announced to cabinet that the government was already broke, and would not have money to fulfil its development and service delivery mandate for the rest of the financial year unless donor budget assistance would be sought and received (The Post, 2018).

Under social weaknesses, the coalitions have polarised the community into two major camps which are bitter enemies and rivals stylistically called nationalists "manasi" for pro ABC and its allies versus congress "macongo" for pro DC and its allies (Weisfelder, undated). This social polarisation has made communities to drift apart and become non cooperative in all other spheres of life including community development issues which require their joined efforts and inclusive benefit sharing.

The other social impact is in relation to the delivery of justice. Coalition governments temper with the top management of the justice system in that the post of president of the appeal court 
of Lesotho is now changed every 2 years when a new coalition government assumes power. That of the Chief Justice is also in the process of being tinkered equally so too. There is much controversy and legal court battles fought by opposing sites on the correctness or incorrectness of this practice (see Carmel Richard, 2018; Qaitsane, 2018b: 6; Kabi, 2018:1; Hoeane, 2018). Meanwhile the community suffers, firstly, in terms of its monies that are used to hire and pay for external judges and commissions to sit on these cases; and secondly through the payments of millions of Rands in lieu of the unserved or partially served contracts terminated prematurely by the government to the affected office bearers. Thirdly community suffers by the delay of justice as there are an estimated more than 4, 000 cases awaiting being heard in the appeal and high courts at present. Justice delayed is justice denied for the communities under coalition governments in Lesotho.

\section{Conclusion and Suggestion}

This paper concludes that while the impacts of the coalition governments on community have had some advantages in Lesotho, these benefits have been overshadowed by tremendous negative impacts such as the political exclusion of the community, promotion of elite self interest at intra party and national levels, political and economic corruption, party factionalism, financial waste on members of parliament and cabinet ministers appeasement benefits/ packages, neglect of community and national development; and short lived government tenures due to collapse of coalitions that have promoted voter apathy, and derailed participatory democracy. The paper recommends that the viable way forward must be sought in electoral constitutional reforms that make it mandatory to have a grand coalition from the onset in the case of a hung government after parliamentary election.

\section{Conflict of Interest}

The author of the article declares no conflict of interest.

\section{Funding}

This research study was not funded by any institution. The author conducted the study on his own expenses.

\section{References}

$3^{\text {rd }}$ Coalition Government of Lesotho (2017): The Coalition Agreement for National Unity, Reconciliation, Peace and Stability. ABC, AD, BNP \& RCL. Maseru.

African News Agency (ANA) (2018): "SA intervenes after the Lesotho King was "mistreated" at the Border." $6^{\text {th }}$ April. Accessed online from https://www.iol.co.za/news/politics/ on 29/05/2018.

Carmel, Richard (2018): "Foreign Judges on Lesotho Bench slam Political Interference in the judicial appointments".fricanLii. Accessed online on 31/05/2018 from https://www.africanlii.org

Department of Politics and International Relations (DPIR) (2015): Coalition government in 
Africa promotes inclusion but hurts accountability. Policy Brief. https://www.politics.ox.ac.uk accessed online on 28/05/2018.

Hoeane, T. (2018): “The Appeal court saga continues". Lesotho Times Newspaper, 29 March, 2018. Accessed from https://www.pressreader.com/lesotho/lesotho-times on 04/05/2018.

International Crisis Group (2015): “Can SADC Facilitate a Sustainable Solution to Lesotho's Crisis?" https://www.crisisgroup.org accessed online on 03/05.2018.

Johnston, R.: Gregory, D. And Smith, D. (1994): The Dictionary of Human Geography. Blackwell. Oxford. Third Edition.

Kabi,P. (2018): “ Thabane Plots Chief Justice's Removal”. Sunday Express Newspaper. 6 May, 2018. Accessed at https://www.pressreader.com/lesotho/sunday-express on $04 / 06 / 2018$.

Kabi, P. (2017): "Lesotho: Big Cabinet No Guarantee for Stability". Lesotho Times Newspaper. 8 July, 2017. Accessed from https://www.allafrica.com on 04/05/2018.

Kadima, D. (undated): "An Introduction to the Politics of Party Alliances and Coalitions in socially divided Africa." Journal of African Elections. 13(1): 1- 24. Accessed online from https://www.eisa.org.za/pdf.JAE13.1Kadima.pdf on 28/05/2018.

Kapa, M. and V. Shale (undated): "Alliances, Coalitions and the Political System in Lesotho 2007-2012." Journal of African Elections. 13 (1): 93-114. Accessed online from https://www.eisa.ac.za/pdf /JAE/13.2 on 28/05/2018.

Letsie, T (2015??): "Lesotho's February 2015 Snap Elections: A Prescription that never cured the Sickness". Journal of African Elections. 14(2): 81-109. Accessed online on 31/05/2018 from https://www.eisa.org.za/pdf /JAE/14.2

Likoti, F. (200): African Military Interventions in African Conflicts: An Analysis of Military Interventions in Rwanda, DRC and Lesotho. $\mathrm{A} \mathrm{PhD}$ Thesis submitted to the University of the Western_Cape. Cape Town.

Glassner, M and Fahrer, C. (2004): Political Geography. John Wiley \& Sons. Hoboken, NJ. Third Edition.

Lesotho Times (2016): “Govt hits back at Americans”. Lesotho Times Newspaper. 16 December, 2016.

Lesotho Times (2018a): "SUPMIL should be given enough time." Comment. Lesotho Times Newspaper. Accessed online from www.lestimes.com/?p=34098 on Tuesday 29 May.

Lesotho Times (2018b): "Leave Metsing Alone please". Comment. Lesotho Times Newspaper. $13^{\text {th }}$ April, 2018.

Mahlakeng, M. (2016): "Lesotho: Dilemma of a Coalition government". Southern African Peace and Security Blog. Saccps.blogspot.jp/2016/

Matlosa, K. And N. Pule (undated): "Civil - Military relations in Lesotho, 1966 - 1998: Prospects and Constraints." Accessed online on 03/05/2018 from https://oldsite.issafrica.org/uploads/UPLOADSOUSELVESMATLOSA.PDF

Mohlobli, K. (2016): "SADC ultimatum for Lesotho". Lesotho Times. 21 January.

Mothibe, T. (1999): "The Military and Democracy in Lesotho" Lesotho Social Sciences Review. 5(1): 47-63.

Oloo, A. (2010): Kenyans and Coalition Government: Disappointment in spite of Relative Peace. Afro Barometer Briefing Paper No. 91. AFROBAROMETER 10 Years.

Perudi, M. (2003): “Operation Boleas under microscope, 1998-1999”. Accessed online from www.journals.ufs.ac.za/ on 31/05/2018.

Qaitsane,S. (2018a): "Lesotho Defence Force (LDF) warrant officers undergo training". Informative Newspaper. 10-15 April, 2018. At www.informativenews.co.ls

Qaitsane, S. (2018b): “Southern African Chief Justices' Forum (SACJF) warns government 
on Chief Justice". Informative Newspaper. 15-21 May, 2018. At www.informativenews.co.ls

Qaitsane, S. (2018a): "Sisulu apologises to King". Informative Newspaper. 10-16 April, 2018. At www.informativenews.co.ls

Sejanamane, M. (2018): Meaning and Implications of Metsing's Incendiary Remarks on his Birthday. Lesothoanalyis blog.

Sunday Express (2020): “Clip the Prime Minister's Powers". Sunday Express Newspaper. Maseru. $26^{\text {th }}$ September.

The Post Newspaper (2018): "Government is broke." 22 June. https://www.thepost.co.ls/news/ Accessed online on 26/06/2018.

Vhumbunu, C. (2015): Appraising the efficacy of SADC Intervention in resolving the 2014 Lesotho Conflict: Progress and Prospects. www.accord.org.za . Accessed online on 04/05/2018.

Weisfelder, R. (undated): "Free Elections and political Instability in Lesotho". Journal of Africa Elections.14 (2): 50-80. https://www.eisa.org visited online on 02/05/2018. 